\title{
ADSORPTION OF BARK DERIVED POLYPHENOLS ONTO FUNCTIONALIZED NANOCELLULOSE: EQUILIBRIUM MODELLING AND KINETICS
}

Bright Asante ${ }^{1}$, Juho Antti Sirviö ${ }^{2}$, Panpan $\mathrm{Li}^{2}$, Anu Lavola ${ }^{3}$, Riitta Julkunen-Tiitto ${ }^{3}$, Antti Haapala $^{1}$, Henrikki Liimatainen ${ }^{2}$

${ }^{1}$ University of Eastern Finland, School of Forest Sciences, 80101 Joensuu, Finland

${ }^{2}$ University of Oulu, Fiber and Particle Engineering, 90014 University of Oulu, Finland

${ }^{3}$ University of Eastern Finland, Department of Environmental and Biological Sciences, 80101 Joensuu, Finland

Correspondence: A Haapala, School of Forest Sciences, Wood Materials Science, Yliopistokatu 7, PO Box 111, University of Eastern Finland, FI-80101, Finland

E-mail: antti.haapala@uef.fi 
Adsorption of bark derived polyphenols onto functionalized nanocellulose: Equilibrium modelling and kinetics

\begin{abstract}
This paper describes the kinetics and capacity of adsorbing condensed conifer tannins onto cationic cellulose nanocrystals (CCNCs). Batch adsorption experiments were carried as a function of $\mathrm{pH}$, contact time and initial tannin concentration with constant cationic cellulose nanocrystal concentration $(0.01 \%)$. The adsorption process was highly $\mathrm{pH}$ dependent as adsorption capacities ranged from $13.2 \mathrm{mg} / \mathrm{g}$ to $112.7 \mathrm{mg} / \mathrm{g}$ at $\mathrm{pH}$ of $3-10$. The amount of tannin adsorbed per unit mass of the cationic cellulose nanocrystals increased with increasing of tannin concentration until equilibrium was attained. The experimental data followed the Langmuir adsorption model, and the maximum experimental and theoretical adsorption capacities for the cationic nanocrystals reached $1008 \mathrm{mg} / \mathrm{g}$ and $1111 \mathrm{mg} / \mathrm{g}$, respectively. The kinetics of adsorption was described best by the pseudo-second-order kinetics indicating a chemisorption process. The inherent adsorption has interesting applications for CCNC-complexes with natural polyphenolics in green chemical applications for e.g. adhesives, adsorbents, preservatives and packaging materials.
\end{abstract}

Keywords: Adsorption isotherm; Biomaterials; Cationic cellulose nanocrystals; Reaction kinetics; Tannin 


\section{INTRODUCTION}

2 Proanthocyanidins such as tannins and other flavonoids are a group of bio-based chemicals

3 traditionally extracted from plant seeds, berry or fruit skins, tree heartwood or bark and novel

4 means to valorize these especially from industrial side streams are ongoing ${ }^{1-5}$. These phenolic,

5 secondary metabolic compounds in plants have traditionally been used in leather industry due to

6 the protein binding capacity and more recently in colloidal complexes intended for food, pharma,

7 chemical and wood product industries ${ }^{6-9}$.

9 Tannin compounds are known for their ability to bind to proteins and compounds such as alkaloids 10 and amino acids, large-molecular compounds and metallic ions. They also present some anti11 oxidant activity that distinguishes them from other plant polyphenols ${ }^{10}$. Haslam found out that 12 tannins form complexes not only with proteins and alkaloids but also with certain 13 polysaccharides ${ }^{11}$. Tannins have been used in glue-mix adhesives to improve internal cross14 linking and to reduce the required volume of adhesives ${ }^{12}$. In addition, they have been used as preservatives in wood and wood products offering protection against light and against deterioration by insects, fungi and bacteria ${ }^{13-15}$. However, the main drawback for the use of tannins in wood and wood products is their high leachability (i.e. tendency to be washed away) in outdoor applications ${ }^{15,16}$. Bonding between tannins and matrices must hence be strong enough to avoid 19 such leakage of tannin.

21 One route to achieve higher retention of tannins in chemical formulations is to combine them with 22 binding compounds ${ }^{17,18}$ or nanoparticles to complexes ${ }^{19}$ that can act as bridging or cross-linking 23 agents between the matrix and tannin. Immobilization of tannin, or specific hydrolysable tannin 
compounds such as tannic acid, onto material surfaces has also been achieved using for instance mesoporous silicate ${ }^{20}$, silica microspheres ${ }^{21}$, collagen ${ }^{22}$, graphene ${ }^{23}$ and activated carbon ${ }^{24}$. As reported by Xu et al. (2017), dialdehyde nanocellulose can be used to covalently immobilize tannin molecules. In case of wood as matrix, carbohydrates with inherently good adhesion with wood can be exploited ${ }^{25}$. However, these carbohydrates must have a suitable structure, composition, as well as a sufficient size and flexibility to be able to complex polyphenols such as tannins in the wood structure $^{26-29}$. Nanocelluloses (i.e. cellulose nanofibers or nanocrystals) with a high aspect ratio and surface area combined with a chemically active structure, are potential agents to encapsulate and complex with polyphenols, and allow them to be incorporated wood matrix. Apart from the particle size, the surface chemistry also play an important role in surface interactions as too much attraction of the complex formed may lead to surface coating and the desired impregnation of voids, cavities and wood cells or lumen is not achieved.

The adsorption performance of modified nanocelluloses may be increased via high specific surface areas and numerous reactive groups ${ }^{30}$. Recent publications have shown uses of modified nanocelluloses in water treatment in adhesion and removal of heavy metals and organic pollutants. In these cases, the surface modification of the nanocellulose was obtained by adding specific groups such as carboxyl ${ }^{31,32}$, amine $\mathrm{e}^{33,34}$, ammonium ${ }^{35}$ and xanthate ${ }^{36}$ on the surface of cellulose. There are several similar studies that report the use of nanocellulose or tannin layered particles in wastewater purification ${ }^{37}$ or metal ion scavenging systems $\mathrm{s}^{25}$ but to our understanding such analysis on the kinetic rate and mode of adsorption between cationic nanocelluloses and wood bark-derived tannins has not been published. In this study, we report the results of the interactions between wood-derived condensed tannins and other polyphenols and cationic cellulose nanocrystals 
(CCNC) obtained from deep eutectic solvent treatment, and especially address the adsorption of bark chemicals onto cellulose nanocrystals. The effect of solution $\mathrm{pH}$, contact time and initial tannin extract concentration on the adsorption was studied in batch experiments in particular, and the adsorption was further modelled using adsorption isotherms and kinetic data.

\section{MATERIALS AND METHODS}

\section{Raw materials and chemicals for making the CCNCs}

Dry sheets of bleached birch Kraft pulp (Betula pendula) were used as the fibre material for the production of the cellulose nanocrystals. Lithium chloride ( $\mathrm{LiCl})(99 \%)$, sodium (meta) periodate $\left(\mathrm{NaIO}_{4}\right)$, were from Sigma-Aldrich (Germany), ethanol $\left(\mathrm{CH}_{3} \mathrm{CH}_{2} \mathrm{OH}\right)(96 \%)$ and glycerol $\left(\mathrm{C}_{3} \mathrm{H}_{8} \mathrm{O}_{3}\right)(97 \%)$ from VWR France, aminoguanadine hydrochloride $\left(\mathrm{CH}_{6} \mathrm{~N}_{4} \cdot \mathrm{HCl}\right)(>98 \%)$ from Tokyo Chemicals Industry, Japan, hydrochloric acid $(\mathrm{HCl})\left(0.1 \mathrm{~mol} / \mathrm{dm}^{3}\right)$ and sodium hydroxide $(\mathrm{NaOH})\left(0.1 \mathrm{~mol} / \mathrm{dm}^{3}\right)$ from Oy FF-chemicals $\mathrm{AB}$, Finland. Acetate buffer $\left(\mathrm{CH}_{3} \mathrm{COOH} /\right.$ $\left.\mathrm{CH}_{3} \mathrm{COONa}, 3 \cdot \mathrm{H}_{2} \mathrm{O}\right)(\mathrm{pH} 3$ and $\mathrm{pH} 5)$, phosphate buffer $\left(\mathrm{NaH}_{2} \mathrm{PO}_{4} / \mathrm{Na}_{2} \mathrm{HPO}_{4}\right)(\mathrm{pH} 7$ and 8$)$ and sodium carbonate buffer $\left(\mathrm{NaHCO}_{3} / \mathrm{Na}_{2} \mathrm{CO}_{3}\right)(\mathrm{pH} 10)$ were from $\mathrm{CH}_{3} \mathrm{COOH}$ and $\mathrm{CH}_{3} \mathrm{COONa}$, $2 \cdot \mathrm{H}_{2} \mathrm{O}$ (Sigma-Aldrich), $\mathrm{NaH}_{2} \mathrm{PO}_{4}$ (Sigma), $\mathrm{Na}_{2} \mathrm{HPO}_{4}$ (Fluka), $\mathrm{NaHCO}_{3}$ (Merck) and $\mathrm{Na}_{2} \mathrm{CO}_{3}$ (J.T. Baker), all of which were p.a. grade, were used as received to prepare buffers. Deionized water was used through the experiments.

\section{Cationization of cellulose}

A two-step method based on consequent periodate oxidation and cationization in deep eutectic solvent was used to produce cationic cellulose. First, disintegrated birch Kraft pulp was oxidized with sodium periodate at temperature $75^{\circ} \mathrm{C}$ to produce dialdehyde cellulose with aldehyde content 
of $3.68 \mathrm{mmol} / \mathrm{g}^{38}$. In brief, $9 \mathrm{~g}$ of lithium chloride $(\mathrm{LiCl})$ and $4.1 \mathrm{~g}$ of sodium periodate $\left(\mathrm{NaIO}_{4}\right)$ were added to water suspension of disintegrated pulp ( $5 \mathrm{~g}$ abs., temperature of pulp $\left.75^{\circ} \mathrm{C}\right)$ in the absence of light for 180 minutes and mixed with magnetic stirrer. The oxidized pulp was filtered and washed with ethanol. The product (dialdehyde cellulose, DAC) was collected and stored at $4^{\circ} \mathrm{C}$ in a non-dried state.

Cationization of DAC was done in deep eutectic solvent (DES) according the method established by Li et al. (2018). Cationization of DAC was done in DES formed between aminoguanadine hydrochloride and glycerol in molar ratio of 1:2. A clear DES solution was obtained by melting the compounds at $90^{\circ} \mathrm{C}$ after which the reaction temperature was adjusted to $70^{\circ} \mathrm{C}$ and DAC $(2.5 \mathrm{~g}$ abs.) was added and mixed for 10 minutes. The flask was removed from oil-bath and $25 \mathrm{ml}$ of ethanol was added. The cationized cellulose was filtered and washed with ethanol after which it was dried in oven at $60^{\circ} \mathrm{C}$. Finally, the product was mixed in $250 \mathrm{ml}$ of deionized water for $1 \mathrm{~h}$ and filtered.

The cationic charge density of cationized DAC (CDAC) was determined using polyelectrolyte titration method by a particle charge detector (BTG Mütek PCD-03, Germany). The CDACs were diluted by deionized water into $0.01 \%$ solution, along with 30 minutes magnetic stirring at room temperature. Then, $10 \mathrm{ml}$ of well dispersed CDAC suspension was titrated with sodium polyethylene sulphonate (PES-Na) polyelectrolyte. The charge density was calculated by the consumption of PES-Na. The charge of the cationic cellulose (in deionized water) was 0.76 $\mathrm{mmol} / \mathrm{g}$. 


\section{Production of cationic cellulose nanocrystals}

Mechanical disintegration was used to liberate cationic cellulose nanocrystals (CCNC) from the modified cellulose as described by our earlier study ${ }^{39}$. First, $1 \%$ CDAC solution was stirred with a magnetic bar for $10 \mathrm{~min}$ and then further disintegrated using a microfluidizer (Microfluidics M110EH-30, USA) with a pressure of 1000 bars. The suspension passed through the microfluidizer chambers (400 and $200 \mu \mathrm{m})$ twice, yielding transparent and low viscous suspension.

\section{Determination of charge density, zeta potential and conductivity of tannin and cellulose} nanocrystals

The anionic and cationic charge density of tannins and cationic cellulose nanocrystals (CCNC) were determined using polyelectrolyte titration with particle charge detector $(\mathrm{PCD}) .0 .01 \%(\mathrm{w} / \mathrm{w})$ tannin and cationic cellulose nanocrystals solution were prepared at different $\mathrm{pH}(3-10)$ and titrated with poly-diallyldimethylammonium chloride and sodium polyelectrolyte sulphonate. All dilutions were done using same buffer solutions used for tannin and nanocrystal sample preparation.

Zeta potential and conductivity measurements were performed on a Zetasizer Nano ZS (Malvern Instruments Ltd., UK). For the measurement, the CCNC suspension and tannin extract were diluted (with $0.5 \mathrm{mM}$ buffer solution at $\mathrm{pH} 3,5,7,8$ and 10) to a concentration of $\sim 0.05 \mathrm{mg} / \mathrm{mL} .1 \mathrm{~mL}$ of cellulose nanocrystals suspension in DTS1070 disposable folded capillary cell was used for the measurement. The average of three (3) replicates were computed for each $\mathrm{pH}$ measured. 
116 Tannin extract (19.4\% dry matter content) was obtained from Natural Resources Institute Finland,

117 Finland, following previously published method ${ }^{40}$. The extract was the raw tannin complexes

118 obtained from spruce bark (Picea abies) using hot water extraction and subsequent spray drying

119 without purification. The tannin concentrate contained $21.3 \mathrm{mg} / \mathrm{mL}$ of soluble condensed tannins.

120 The average chain length of the tannin was six catechin-units, giving about 2320 for total molecular

121 mass. In addition, the concentrate was composed of many other low molecular weight phenols,

122 such as phenolic acids, flavonoids, lignans, neolignans and stilbenes (Table 1). There was also a

123 group of unidentified compounds with similar UV-spectra, which were likely polymers of

124 decomposed stilbenes with increasing mass of methyl-groups attached.

126 The acid-butanol assay for proanthocyanidin analysis ${ }^{41}$ was used to determine the amount of 127 soluble condensed tannins in the tannin extract. The samples of 10-30 microliters were diluted up $1281 \mathrm{ml}$ of methanol, $6 \mathrm{ml}$ of $\mathrm{HCl}$-butanol (20:1) solution and $2 \% \mathrm{FeNH}_{4}\left(\mathrm{SO}_{4}\right)_{2}$ reagent was added.

129 The mixture was incubated for 50 minutes at $100^{\circ} \mathrm{C}$. The absorbance of solutions was measured at $130550 \mathrm{~nm}$ using a photometer (Spectronic 20 GenesysTM), and the results were standardized with 131 purified tannins from the bark of spruce, Picea abies. The degree of the polymerization of the 132 tannins in the extract was determined by the phloroglucinol method with HPLC ${ }^{41}$. Shortly, the 133 samples of the tannin extract were incubated with phloroglucinol in acidic ethanol at room 134 temperature overnight. The formed phloroglucinol-derivatized extender units and unreacted 135 terminal units of flavanols were extracted into ethyl acetate and analysed by HPLC. Comparison 136 of the peak areas gave the average chain length for the proanthocyanidins (condensed tannins). 
For the analysis of individual phenolic compounds, samples of 50 or $100 \mu 1$ of concentrated tannin extract was dissolved into $100 \mu 1$ of methanol, identified UHPLC-qtof MS and quantified with HPLC-DAD system (HP 1100 series, Agilent Technologies, Palo Alto, CA, USA) according to

141 Taulavuori et al. ${ }^{42}$. The column used in HPLC-DAD was Zorbax $3.5 \mu \mathrm{m}, 4.6 \times 75 \mathrm{~mm}$, and 142 injection volume was $20 \mu \mathrm{l}$. The eluents used were aqueous $1.5 \%$ tetrahydrofuran $+0.25 \%$ 143 orthophosphoric acid (A) and methanol (B). The following gradient was used: $0-5$ min 100\% A, $1445-10 \min 85 \% \mathrm{~A}+15 \% \mathrm{~B}, 10-20 \min 70 \% \mathrm{~A}+30 \% \mathrm{~B}, 20-45 \min 50 \% \mathrm{~A}+50 \% \mathrm{~B}, 45-65 \min$ $145100 \% \mathrm{~B}, 65-70 \mathrm{~min} 100 \% \mathrm{~A}$. The flow rate was $2 \mathrm{ml} / \mathrm{min}$, the injector temperature was $23^{\circ} \mathrm{C}$ and 146 the column temperature was $30^{\circ} \mathrm{C}$. Detection wavelengths were $220 \mathrm{~nm}, 270 \mathrm{~nm}$ and $320 \mathrm{~nm}$.

148 Identification and quantification of the compounds were based on their mass, retention times, UV-

149 VIS spectra and the commercial standard compounds: gallic acid (Sigma-Aldrich Finland Oy, 150 Helsinki, Finland); protocatechuic acid (Carl Roth, Karlsruhe, Germany); cinnamic acid (Sigma151 Aldrich Finland Oy, Helsinki, Finland); ferulic acid (Carl Roth, Karlsruhe, Germany); ampelopsin 152 (Carl Roth, Karlsruhe, Germany); taxifolin (Extrasynthése, Genay, France); (+)-catechin (Fluka 153 Chemie AG, Buchs, Switzerland) for (+)-catechin and neolignans; piceatannol (Extrasynthése, 154 Genay, France) for all stilbenoids. Analytical grade piceatannol (BioNordika Ltd, Finland) was 155 also used as monomer compound in adsorption reference studies.

\section{Adsorption experiments}

158 Figure 1 show tannin extract and CCNC used for the adsorption experiment. The adsorption 159 experiments were carried out at $\mathrm{pH} 3,5,7,8$ and 10 by mixing $25 \mathrm{ml}$ of the $0.02 \%$ tannin solution 160 with $25 \mathrm{ml}$ of $0.02 \%$ of cationic cellulose nanocrystals solution in Gallenhamp GWB flash shaker 

at room temperature $\left(25^{\circ} \mathrm{C}\right)$ for 24 hours. For the monomer compound, the experiments were made using $0.02 \%$ concentrations of both nanocellulose and piceatannol at $\mathrm{pH} 5$ and 8 . The acetate $(\mathrm{pH}$ 3 and 5), phosphate ( $\mathrm{pH} 7$ and 8$)$ and sodium carbonate ( $\mathrm{pH} 10)$ buffer solutions $(0.5 \mathrm{mM})$ were used to adjust the $\mathrm{pH}$. After adsorption, $10 \mathrm{ml}$ of solution was filtered using a syringe filter $(0.2$ $\mu \mathrm{m})$ and the concentration of tannin in the filtrate was determined via calibration curve. All absorbance were determined using the Shimadzu UV-1800 spectrophotometer. Absorbance values were measured at wavelength of $280-282 \mathrm{~nm}$ depending on the absorbance maximum at that $\mathrm{pH}$. For piceatannol the absorbance maximum was measured at wavelength of $322 \mathrm{~nm}$. The amount of tannin adsorbed per unit mass of cationic cellulose nanocrystals $Q e(\mathrm{mg} / \mathrm{g})$ were calculated using:

173 Where: $Q e=$ equilibrium adsorption capacity $(\mathrm{mg} / \mathrm{g}), C e=\operatorname{tannin}$ concentration at equilibrium

$174(\mathrm{mg} / \mathrm{L}), C o=$ Initial concentration of tannin $(\mathrm{mg} / \mathrm{L}), W=$ mass of cationic cellulose nanocrystal $175(\mathrm{~g}), V=$ volume of solution $(\mathrm{L})$.

\section{Kinetics studies}

178 The kinetics studies were similar to the $\mathrm{pH}$ effect studies; however they were conducted at $\mathrm{pH} 8$.

179 At different time intervals (5-1440 minutes), $5 \mathrm{ml}$ of the solution in the Scott bottle was drawn, 180 filtered and analyzed using the Shimadzu UV-1800 spectrophotometer. The amount of tannin 181 adsorbed per unit mass of cationic cellulose nanocrystals $Q t(\mathrm{mg} / \mathrm{g})$ were evaluated using: 
183

$Q t=\frac{C o-C e}{W} V$

184 Where: $Q t=$ adsorption capacity at time t.
186

187

188

189

190

191

192

193

194

195

196

197

198

199

200

201

202

203

204

\section{Effect of tannin concentration on the adsorption}

The effect of tannin concentration on adsorption was studied at $\mathrm{pH} 8$ using contact time of 1440 minutes. The tannin concentration was varied from $0.002-1.0 \%$. The amount of tannin adsorbed per unit mass of cationic cellulose nanocrystals $Q e(\mathrm{mg} / \mathrm{g})$ were evaluated using Equation 1.

Tannin solutions of different concentrations $(0.001-0.05 \%)$ were prepared in $0.5 \mathrm{mM}$ acetate buffer (pH 3 and $\mathrm{pH}$ 5), phosphate buffer ( $\mathrm{pH} 7$ and 8) and sodium carbonate buffer (pH 10). The UV absorbance of the samples was recorded at wavelength of 190-800 nm against a deionized water as a blank or reference using a Shimadzu UV-1800 spectrophotometer. A $10 \mathrm{~mm}$ quartz cuvette was used. There were three different absorption maximums or peaks for the different UV spectrums (i.e. peaks were observed UV-C at $200 \mathrm{~nm}, \mathrm{UV}-\mathrm{B}$ at 280-282 nm and UV-A at $317 \mathrm{~nm}$ and $318 \mathrm{~nm}$ depending on the $\mathrm{pH}$ of the tannin solution). Calibration curve were made for each $\mathrm{pH}$ by plotting the absorbance at $280-282 \mathrm{~nm}$ against concentration.

\section{RESULTS AND DISCUSSION}

Effect of the $\mathrm{pH}$ on the tannin and piceatannol adsorption on cationic cellulose nanocrystals Figure 2 shows the adsorption of the tannin on the $\mathrm{CCNC}$ as a function of $\mathrm{pH}$. The adsorption was found to be highly $\mathrm{pH}$ dependent and adsorption capacity increase from $13.2 \mathrm{mg} / \mathrm{g}$ to $86.36 \mathrm{mg} / \mathrm{g}$ was observed when the $\mathrm{pH}$ was increased from 3 to 7 . With higher $\mathrm{pH}$ values (from 7 to 10 ) the 
adsorption capacity ranged from $86.4 \mathrm{mg} / \mathrm{g}$ to $112.7 \mathrm{mg} / \mathrm{g}$, showing slight slower changes in the uptake.

The adsorption of piceatannol to cationic cellulose nanocrystal were studied at $\mathrm{pH} 5$ and $\mathrm{pH} 8$. Adsorption capacities were $3.98 \mathrm{mg} / \mathrm{g}$ at $\mathrm{pH} 5$ and $11.90 \mathrm{mg} / \mathrm{g}$ at $\mathrm{pH} 8$. At $\mathrm{pH} 8$ some change in the color due to piceatannol oxidation was observed but its impact on structure and adsorption

211 behavior could not be assessed. The tannin extract compounds were also subject to oxidation 212 during extraction, storage and usage.

214 The $\mathrm{pH}$ of the adsorption environment is crucial as it affects the surface charge or the ionic state 215 of the adsorbate (tannin extract) and adsorption capacity of the adsorbent (CCNC), due to acid216 base reactions between surface functional groups and solution ${ }^{43}$. Here, the low adsorption capacity 217 at low $\mathrm{pH}$ values was likely attributed to protonation of tannins, which in turn reduced the 218 electrostatic attractive interaction with cationic nanocrystals.

At higher $\mathrm{pH}$ values, the degree of deprotonation of the phenolic hydroxyls in the tannins increased $^{44,45}$, while nanocrystals still maintained their cationic charge. This charge behavior resulted in attractive interaction between the tannins and CCNC, and increased the capacity of adsorption. The dependency of tannin extract and CCNC charge in different $\mathrm{pH}$ is provided in

224 Table 2. The results clearly show that the anionic charge of tannin extract increased as a function 225 of $\mathrm{pH}$, while the cationic charge of $\mathrm{CCNC}$ showed only slight decrease up to $\mathrm{pH}$ of 8 . For studying 226 the influence of tannin concentration on $\mathrm{CCNC}$ adsorption and kinetics of adsorption, the $\mathrm{pH}$ value of 8 , which still showed a high capacity, was used. 
229 The zeta potential and conductivity of $\mathrm{CCNC}$ and tannin extract at different $\mathrm{pH}$ values are shown 230 in Table 2. Values for piceatannol monomer were $-10.11 \mathrm{mV}$ and $0.063 \mathrm{mS} / \mathrm{cm}$ for $\mathrm{pH} 8$, 231 respectively. The CCNC used in this work holds with amino group; whilst tannin extract contains 232 phenolic $-\mathrm{OH}$ groups that show ionization in solutions at high $\mathrm{pH}$ medium. From the Table 2, the 233 zeta potential of $\mathrm{CCNC}$ was positive across the $\mathrm{pH}$ range studied, which is attributed to the 234 presence of the protonated amino groups. The tannin compounds, on the other hand, had negative 235 charge across $\mathrm{pH}$ range and could therefore attach easily to the $\mathrm{CCNC}$ easily via electrostatic 236 attraction.

\section{Effect of the contact time on the tannin adsorption on CCNC}

239 The effect of contact time on adsorption of tannin on CCNC is presented in Figure 3. The 240 adsorption consisted of fast initial stage (first 15 minutes) and a slower plateau-stage after that. 241 The adsorption capacity of $75.7 \mathrm{mg} / \mathrm{g}$ was obtained already after $5 \mathrm{~min}$ of adsorption and relative 242 small differences were found in the adsorption capacities between 120 minutes to 360 minutes $243 \quad(86-90 \mathrm{mg} / \mathrm{g})$.

245 Similar observation ${ }^{46}$ was reported on a two stage adsorption mechanism in the adsorption of 246 copper ions on cross-linked chitin-cellulose beads, chitosan-red soil beads and chitosan-banana 247 stem fiber beads with the first rapid and the second slower stages. Here the adsorption rate was 248 extremely high at the beginning, indicating that tannin was adsorbed by a readily available 249 adsorption $\operatorname{sites}^{30,47}$, after which the sites with more difficult to achieve were occupied ${ }^{46}$. This 250 implies that reasonable immobilization of tannin components onto nanocellulose can take place 
significantly faster than used in most contemporary investigations where the adsorption process is carried out for several hours ${ }^{18,25,48,49}$. Process efficiency of a shorter reaction time was apparent in the study by Li et al. ${ }^{50}$ in which the production of nanocellulose-tannin films required only 10

254 minute reaction time between system components.

\section{Adsorption kinetics}

In order to describe the kinetics of tannin adsorption, the linear forms of the pseudo-first-order (Equation 3) proposed by Lagergren ${ }^{51}$ and pseudo-second-order (Equation 4) by Ho et al. ${ }^{52}$, were used:

$\frac{t}{Q t}=\frac{1}{K a(Q e)^{2}}+\frac{t}{Q e}$

264 Where $Q t$ and $Q e$ are adsorption capacities at time $\mathrm{t}$ and at equilibrium, respectively $(\mathrm{mg} / \mathrm{g}), K i=$ 265 rate constant of the pseudo-first-order adsorption $(1 / \mathrm{min}), K a=$ rate constant of the pseudo266 second-order adsorption $(\mathrm{g} / \mathrm{mg} \cdot \mathrm{min})$. The values of $K i$ and $K a$ were determined from the plots of $\ln (Q e-Q t)$ vs $t$ and $t / Q t$ vs $t$, respectively (Figure 4).

269 The results from the adsorption kinetics obtained from the two models are presented in Table 3 270 and Figure 4. The correlation coefficient $\left(\mathrm{R}^{2}\right)$ followed the order: pseudo-second-order $>$ pseudo271 first-order (Table 3). The Qe calculated from the pseudo-second-order adsorption matches well 272 with that from the experiment compared to Qe of pseudo-first-order (Table 3). The pseudo-second273 order also had a correlation coefficient close to unity. This confirms that the data is well fitting by 
274 the pseudo-second-order kinetics for the entire sorption period. The fitting model suggests that 275 adsorption step could be dominated by chemisorption, involving sharing or exchange of electrons 276 between adsorbent and adsorbate ${ }^{53}$.

\section{Effects of the initial tannin extract concentration on the tannin's adsorption on CCNCs}

The adsorption of tannin on cationic cellulose nanocrystals was studied from initial tannin concentration of $0.002-1 \%$. The adsorption capacity ranged from $11.1 \mathrm{mg} / \mathrm{g}$ to $1007.9 \mathrm{mg} / \mathrm{g}$ and increased as function of tannin concentration until equilibrium was attained (Figure 5). Simple scheme to illustrate the electrostatic attraction between CCNCs and tannin extract constituents at random bonding sites is shown in Figure 6. The lower relative removal (added vs. adsorbed tannin) at higher concentrations resulted from an increased ratio of moles of tannin to the available adsorption sites on nanocrystals surface; hence, fractional adsorption becomes dependent on initial concentration. At optimal conditions the achieved tannin addition to CCNC $(100 \%(\mathrm{w} / \mathrm{w}))$ clearly exceeds the previously reported yields of $67 \%$ by Xu et al. ${ }^{25}$ and $42.3 \%$ by Huang et al. ${ }^{54}$.

Mezenner and Bensmaili ${ }^{55}$ stated that for a given adsorbent dose the total number of available adsorption sites is fixed thereby adsorbing almost the same amount of adsorbate. The initial tannin concentration provides an important driving force to overcome the mass transfer resistance of tannin between the buffer solution and crystal phases. Thus, at higher initial tannin concentration, the number of ions competing for the available adsorption sites on the CCNC was high, hence, 294 resulting in the higher adsorption capacity ${ }^{56}$.

\section{Adsorption isotherms}


The adsorption equilibrium data was analyzed using Langmuir and Freundlich isotherms expression. The Langmuir model is based on the assumption that the maximum adsorption corresponds to a saturated monolayer of solute molecules on the adsorbent surface ${ }^{57}$. The

300 Langmuir equation is given in the linear form as:

$301 \quad \frac{C e}{Q e}=\frac{1}{Q m} C e+\frac{1}{K l \times Q m}$

302

303

Slope $=\frac{1}{Q m}$, Intercept $=\frac{1}{K l \times Q m}$

304 The separation factor, $R l$ is an important parameter in the Langmuir model indicating the 305 favorability of the adsorption and is calculated as:

$306 \quad R l=\frac{1}{1+(K l \times C o)}$

307

where $K l$ is Langmuir constant and $C o$ is the highest initial concentration $(\mathrm{mg} / \mathrm{L}) . R l>1$ is unfavorable, $R l=1$ is linear, $R l=0$ is irreversible, $0<R l<1$ is favorable for the adsorption.

310

311 Freundlich model can be used for non-ideal sorption that involves heterogeneous surface energy

312 systems $^{58}$. It is expressed in the linear form as:

313

$$
\ln (Q e)=1 n(K f)+\frac{1}{n F} \ln (C e)
$$

$314 \quad$ Slope $=\frac{1}{n F}$, Intercept $=1 n(K f)$ 
316 Where $C e=$ tannin concentration at equilibrium $(\mathrm{mg} / \mathrm{L}), Q e=$ equilibrium adsorption capacity

317 (mg/g), $Q m=$ maximum adsorption capacity $(\mathrm{mg} / \mathrm{g}), K l=$ Langmuir adsorption constant $(\mathrm{L} / \mathrm{mg})$,

$318 K f=$ Freundlich constant $(\mathrm{L} / \mathrm{mg}), n F=$ heterogeneity factor of adsorption sites (dimensionless).

$K f$ is a rough indicator of the magnitude of the adsorption capacity whereas $1 / n F$ describes the adsorption intensity. Value of $n F>1$ indicates favorable adsorption conditions ${ }^{59,60}$. In general, the Langmuir model assumes that the surface of the adsorbent is energetically homogenous while the Freundlich model considers for a multisite adsorption for heterogeneous surfaces and is 324 characterized ${ }^{61,62}$ by heterogeneity factor $1 / n F$.

Linearized Langmuir and Freundlich isotherm models for tannin adsorption on CCNC are presented in Figure 7A and 7B, respectively, with details of the models outcomes given in Table 4. The value of $\mathrm{R}^{2}$ for the Langmuir model (0.99) was found to be higher than that of the Freundlich model (0.83) indicating that the data from this experiment is best fitting for the Langmuir isotherm.

330 This result suggests physical adsorption as well as homogenous distribution of active sites on the 331 surface of the cationic cellulose nanocrystals. The adsorption of tannin extract constituents and 332 piceatannol on cationic $\mathrm{CNC}$ surfaces can be described as an interaction between opposite charges 333 that tend to be mostly endothermic and purely entropy-driven ${ }^{63}$. The maximum adsorption capacity 334 obtained from Langmuir model was also close to experimentally determined value $(1111.1 \mathrm{mg} / \mathrm{g}$ 335 vs $1007.9 \mathrm{mg} / \mathrm{g})$. The $R l$ value of $0.99(0<R l<1)$ also indicated favorable adsorption (Table 4). 
338 Adsorption of condensed tannin extract from Norway spruce bark onto CCNC was found to be a 339 strongly $\mathrm{pH}$ dependent process that follows the Langmuir adsorption model of monolayer 340 adsorption with the highest adsorption capacity attained at $1111 \mathrm{mg} / \mathrm{g}$. The adsorption of the 341 tannins to the nanocrystals was highly efficient due to electrostatic force of attraction between the $342 \mathrm{CCNC}$ and the tannins, increasing up to $\mathrm{pH} 8$ as a function of systems' $\mathrm{pH}$. The kinetic modelling 343 studies also showed that the experimental data followed a pseudo-second-order kinetics indicating 344 a step-wise chemisorption process.

\section{ACKNOWLEDGEMENTS}

347 This work was supported by a Tekes funded research project "SafeWood" 2723/31/2015 and 348 3368/31/2015. Dr. Petri Kilpeläinen from Natural Resources Institute Finland (Luke) is gratefully 349 acknowledged for providing the sample of hot water extracted spruce bark tannin used in this 350 study. Also, the contribution of Mr. Peiwen Liu from University of Göttingen is acknowledged in 351 analyzing the zeta potential and conductivity of CNCCs and tannin extract. 


\section{REFERENCES}

1 Vivas N, Nonier M-F, Pianet I, De Gaulejac NV, Fouquet É. Proanthocyanidins from Quercus petraea and $Q$ robur heartwood: quantification and structures Comptes Rendus Chim 2006;9(1):120-126.

2 Chemler JA, Koffas MA. Metabolic engineering for plant natural product biosynthesis in microbes. Current Opinion in Biotechnol. 2008;19:597-605.

3 Pizzi A. Tannins: major resources, properties and applications. In: Belgacem, M N, Gandini, A (Eds), Monomers, Polymers and Composites from Renewable Sources. Elsevier; 2008.

4 Bianchi S, Kroslakova I, Janzon R, Mayer I, Saake B, Pichelin F. Characterization of condensed tannins and carbohydrates in hot water bark extracts of European softwood species. Phytochem. 2015;120:53-61.

5 Ding T, Bianchi S, Ganne-Chédeville C, Kilpeläinen P, Haapala A, Räty T. Life cycle assessment of tannin extraction from spruce bark. iForest J. 2017;10:807-814.

6 Carn F, Guyot S, Baron A, Pérez J, Buhler E, Zanchi D. Structural Properties of Colloidal Complexes between Condensed Tannins and Polysaccharide Hyaluronan. Biomacromolecules 2012;13(3):751-759.

7 Anttila AK, Pirttilä AM, Häggman H, Harju A, Venäläinen M, Haapala A, Holmbom B, Julkunen-Tiitto R. Condensed conifer tannins as antifungal agents in liquid culture. Holzforsch. 2013;67(7):825-832.

8 Tondi G, Palanti S, Wieland S, Thevenon MF, Petutschnigg A, Schnabel T. Durability of tanninboron-treated timber. BioRes. 2012;7:5138-5151. 
9 Pranantyo D, Xu LQ, Neoh K-G, Kang E-T, Ng YX, Teo SL-M. Tea stains-inspired initiator primer for surface grafting of antifouling and antimicrobial polymer brush coatings. Biomacromolecules 2015;16(3):723-732.

10 Okuda T, Ito H. Tannins of constant structure in medicinal and food plants hydrolyzable tannins and polyphenols related to tannins. Mol 2011;16:2191-2217.

11 Haslam E. Practical polyphenolics: from structure to molecular recognition and physiological function. Cambridge University Press; 1998.

12 Moubarik A, Pizzi A, Charrier F, Allala A, Badia M, Mansouri HR, Charrier B. Mechanical characterization of industrial particleboard panels glued with cornstarch-mimosa tannin-urea formaldehyde resins. J. Adhes. Sci. and Technol. 2013;27:423-429.

13 Laks PE, McKaig PA, Hemingway RW. Flavonoid biocides: wood preservatives based on condensed tannins. Holzforsch. 1988;42:299-306.

14 Thevenon MF, Tondi G, Pizzi A. High performance tannin resin-boron wood preservatives for outdoor end-uses. Eur. J. Wood Wood Prod. 2009;67:89-93.

15 Tondi G, Schnabel T, Wieland S, Petutschnigg A. Surface properties of tannin treated wood during natural and artificial weathering. Int. Wood Prod. J. 2013;4:150-157.

16 Tondi G, Thevenon MF, Mies B, Standfest G, Petutschnigg A, Wieland S, Impregnation of Scots pine and beech with tannin solutions: effect of viscosity and wood anatomy in wood infiltration. Wood Sci. Technol. 2013;47:615-626.

17 Weckman NE, Olsson ALJ, Tufenkji N. Evaluating the binding of selected biomolecules to cranberry derived proanthocyanidins using the quartz crystal microbalance. Biomacromolecules 2014;15(4):1375-1381. 
18 Wang G, Chen Y, Xu G, Pei Y. Effective removing of methylene blue from aqueous solution by tannins immobilized on cellulose microfibers. Int. J. Biol. Macrom. 2019;129:198-206.

19 Zhou Y, Zhong J, Pan R, Wan Z, Guo J, Wang J, Yin S, Yang X. Zein/tannic acid complex nanoparticles-stabilised emulsion as a novel delivery system for controlled release of curcumin. Int. J. Food Sci. Technol. 2017;52:1221-1228.

20 Gao J-K, Zhang Z-J, Jiang Y-J, Chen Y, Gao S-F. Biomimetic-functionalized, tannic acidtemplated mesoporous silica as a new support for immobilization of NHase. Molecules 2017;22:1597-1609.

21 Fan R, Min H, Hong X, Yi Q, Liu W, Zhang Q, Luo Z. Plant tannin immobilized $\mathrm{Fe}_{3} \mathrm{O}_{4} @ \mathrm{SiO}_{2}$ microspheres: A novel and green magnetic bio-sorbent with superior adsorption capacities for gold and palladium. J. Haz. Mat. 2019;364:780-790.

22 Huang X, Liao X, Shi B. Hg(II) removal from aqueous solution by bayberry tanninimmobilized collagen fiber. J. Haz. Mat. 2009;170:1141-1148.

23 Luo J, Zhang N, Lai J, Liu R, Liu X. Tannic acid functionalized graphene hydrogel for entrapping gold nanoparticles with high catalytic performance toward dye reduction. J. Haz. Mat. 2015;300:615-623.

24 Gong X, Weiguang L, Wang K, Jinhua H. Study of the adsorption of Cr(VI) by tannic acid immobilised powdered activated carbon from micro-polluted water in the presence of dissolved humic acid. Biores. Tech. 2013;141:145-151.

$25 \mathrm{Xu}$ Q, Wang Y, Jin L, Wang Y, Qin M. Adsorption of $\mathrm{Cu}(\mathrm{II}), \mathrm{Pb}(\mathrm{II})$ and $\mathrm{Cr}(\mathrm{VI})$ from aqueous solutions using black wattle tannin-immobilized nanocellulose. J. Haz. Mat. 2017;339:91-99.

26 Brook AJW, Munday KC. The interactions of phenols, anilines, and benzoic acids with sephadex gels. J. Chromatogr. 1970;47:1-8. 
27 McManus JP, Davis K, Beart JE, Gaffney SH, Lilley TH, Haslam E. Polyphenol interactions: Part I Introduction Some observation on the reversible complexation of polyphenols with proteins and polysaccharides. J. Chem. Soc. Perkins Transaction 2, 1985;1429-1438.

28 Ozawa T, Lilley TH, Haslam E. Polyphenol interaction: astringency and the loss of astringency in ripening fruit. Phytochem. 1987;26:2937-2942.

29 De Freitas V, Carvalho E, Mateus M. Study of carbohydrate influence on protein-tannin aggregation by nephelometry. Food Chem. 2003;81:503-509.

30 Hokkanen S, Repo E, Suopajärvi T, Liimatainen H, Niinimaa J, Sillanpää M. Adsorption of $\mathrm{Ni}(\mathrm{II}), \mathrm{Cu}(\mathrm{II})$ and $\mathrm{Cd}(\mathrm{II})$ from aqueous solutions by amino modified nanostructured microfibrillated cellulose. Cellul. 2014;21:1471-1487.

31 Donia AM, Atia AA, Abouzayed FI. Preparation and characterization of nano- magnetic cellulose with fast kinetic properties towards the adsorption of some metal ions. Chem. Eng. J. 2012;191:22-30.

32 Yu X, Tong S, Ge M, Wu L, Zuo J, Cao C, Song W. Adsorption of heavy metal ions from aqueous solution by carboxylated cellulose nanocrystals. J. Environ. Sci. 2013;25:933-943.

33 Sun X, Yang L, Li Q, Zhao J, Li X, Wang X, Liu H. Amino-functionalized magnetic cellulose nanocomposite as adsorbent for removal of Cr(VI): Synthesis and adsorption studies. Chem. Eng. J. 2014;241:175-183.

34 Singh K, Arora JK, Sinha JMT, Srivastava S. Functionalization of nanocrystalline cellulose for decontamination of $\mathrm{Cr}(\mathrm{III})$ and $\mathrm{Cr}(\mathrm{VI})$ from aqueous system: computational modeling. Clean. Technol. and Environ. Policy 2014;16:1179-1191.

$35 \mathrm{Lu}$ M, Xu Y, Guan X, Wei D. Preliminary research on Cr(VI) removal by bacterial cellulose. J. Wuhan Uni. Technol.-Mater. Sci. 2012;25:572-575. 
36 Saumya SP, Deepa B, Abraham E, Girija N, Geetha P, Jacob L, Koshy M. Biosorption of Cd(II) from aqueous solution using xanthated nano banana cellulose: Equilibrium and kinetic studies. Ecotoxicol. and Environ. Saf. 2013;98:352-360.

37 Sánchez-Martín J, Beltran-Heredia J, Delgado-Regaña A, Rodríguez-Gonzáles MA, RubioAlonso F. Optimization of tannin rigid foam as adsorbents for wastewater treatment. Ind. Crops. Prod. 2013;49:507-514.

38 Sirviö J, Hyväkkö U, Liimatainen H, Niinimäki J, Hormi O. Periodate oxidation of cellulose at elevated temperatures using metal salts as cellulose activators. Carbohydr. Polym. 2011;83:12931297.

39 Li P, Sirviö JA, Asante B, Liimatainen H. Recyclable deep eutectic solvent for the production of cationic nanocelluloses. Carbohydr. Polym. 2018;199:217-227.

40 Kilpeläinen PO, Hautala SS, Byman OO, Tanner LJ, Korpinen RI, Lillandt MK, Pranovich AV, Kitunen VH, Willför SM, Ilvesniemi HS. Pressurized hot water flow-through extraction system scale up from the laboratory to the pilot scale. Green Chem. 2014;16(6):3186-3194.

41 Hagerman AE. Tannin Handbook Department of Chemistry and Biochemistry, Miami University, Oxford; 2011. http://wwwusersmuohioedu/hagermae/tanninpdf (Accessed 18 January 2017).

42 Taulavuori K, Hyöky V, Oksanen J, Taulavuori E, Julkunen-Tiitto R. Species-specific differences in synthesis of flavonoids and phenolic acids under increasing periods of enhanced blue light. Environ. Exp. Bot. 2016;121:145-150.

43 Liu P. Adsorption behavior of heavy metal ions from aqueous medium on nanocellulose. Doctoral thesis Printed by Luleå University of Technology, Graphic Production; 2015. 
44 Glazer AN, Smith EL. Phenolic hydroxyl ionization in Papain. J. Biol. Chem. 1961;236(11):2948-2951.

45 Cannas A. Tannins: fascinating but sometimes dangerous molecules. 2015 http://poisonousplantsanscicornelledu/toxicagents/tanninhtml (Accessed 18 January 2017).

46 Thilagan J, Gopalakrishnan S, Kannadasan T. A comparative study on adsorption of copper (ii) ions in aqueous solution by; (a) chitosan blended with cellulose and cross linked by formaldehyde, (b) chitosan immobilized on red soil, (c) chitosan reinforced by banana stem fiber. Int. J. Appl. Eng. Technol. 2013;3(1):35-60.

47 Dong C, Zhang H, Pang Z, Liu Y, Zhang F. Sulfonated modification of cotton linter and its application as adsorbent for high-efficiency removal of lead (II) in effluent. Biores. Technol. 2013;146:512-518.

48 Pei Y, Wu X, Xu G, Sun Z, Zheng X, Liu J, Tang K. Tannin-immobilized cellulose hydrogel fabricated by a homogeneous reaction as a potential adsorbent for removing cationic organic dye from aqueous solution. Int. J. Biol. Macrom. 2017;103:254-260.

49 Dai H, Huang Y, Huang H. Enhanced performances of polyvinyl alcohol films by introducing tannic acid and pineapple peel-derived cellulose nanocrystals. Cellul. 2018;25:4623-4637.

50 Li P, Sirviö J, Haapala A, Khakalo A, Liimatainen H. Anti-oxidative and UV-absorbing biohybrid film of cellulose nanofibrils and tannin extract. Food Hydrocolloids 2019;92:208-217. 51 Lagergren S. Zur theorie der sogenannten adsorption geloster stoffe. Kungliga Sevenska Vetenskapasakademiens Handlingar, 1898;24:1-39.

52 Ho YS, Mckay G, Wase DAJ, Forster CF. Study of the sorption of divalent metal ions on to peat. Adsorption Sci. and Technol. 2000;18:639-650. 
53 Ho YS, McKay G. Pseudo-second order model for sorption processes. Process Biochem. 1999;34:451-465

54 Huang X, Wang YP, Liao XP, Shi B. Adsorptive recovery of $\mathrm{Au}^{3+}$ from aqueous solutions using bayberry tannin-immobilized mesoporous silica. J. Haz. Mat. 2010;183:793-798.

55 Mezenner NY, Bensmaili A. Kinetics and thermodynamic study of phosphate adsorption on iron hydroxide-eggshell waste. Chem. Eng. J. 2009;147:87-96.

56 Idris MN, Ahmad ZA, Ahmad MA. Adsorption Equilibrium of Malachite Green Dye onto Rubber Seed Coat Based Activated Carbon. Int. J. Basic and Applied Sci. 2011;11:305-311.

57 Langmuir I. The adsorption of gases on plane surfaces of glass, mica and platinum. J. Am. Chem. Soc. 1918;40(9):1361-1403.

58 Freundlich H. Over the adsorption in solution. J. Phys. Chem. 1906;57:384-470.

59 Treybal RE. Mass Transfer Operations (second ed.). McGraw Hill (Part 4); 1968.

60 Ho YS, McKay G. Sorption of dye from aqueous solution by peat. Chem. Eng. J. 1998;70:115124.

61 Bouberka Z, Khenifi A, Sekrane F, Bettahar N, Derriche Z. Adsorption of direct red on bentonite modified by cetyltrimethylammoniumbromide. Chem. Eng. J. 2008;136:295-305.

62 Gupta VK, Ali I, Saini VK. Adsorption studies on the removal of Vertigo Blue 49 and Orange DNA13 from aqueous solutions using carbon slurry developed from a waste material. J. Colloid. and Interface Sci. 2007;315(1):87-93.

63 Lombardo S, Thielemans, W. Thermodynamics of adsorption on nanocellulose surfaces. Cellul. 2019;26(1):249-279. 


\section{List of Table Captions}

Table 1. Concentrations of the main phenolic compounds in the concentrated tannin extract

Table 2. Charge dependency and zeta potential of tannin extract and CCNC particles (pH range 3-10)

Table 3. Estimated values of constants of kinetics for the adsorption of tannin extract to CCNCs

Table 4. The parameters of Langmuir and Freundlich isotherms for the adsorption of tannins to cationic cellulose nanocrystals

\section{List of Figure Captions}

Figure 1. Materials used in the experiments, from left: tannin extract, water suspension of nanocellulose crystals (0.64\%), TEM image on CCNCs used, below the chemical structure of CCNC.

Figure 2. Effects of $\mathrm{pH}$ on the adsorption capacity of tannin to CCNC.

Figure 3. Effect of the contact time on the adsorption capacity of tannin on $\mathrm{CCNC}(\mathrm{pH}$ of 8).

Figure 4. Pseudo- first- order (4A) and Pseudo- second- order (4B) kinetics for the adsorption of tannin extract to CCNCs.

Figure 5. Effect of the initial tannin extract concentration on its adsorption capacity on cationic cellulose nanocrystals ( $\mathrm{pH}$ of 8 , adsorption time of 1440 minutes).

Figure 6. Scheme representing the adsorption of tannin extract components on random sites of cationic cellulose nanocrystals driven by electrostatic force of attraction.

Figure 7. Linear fit for the Langmuir model (7A) and Freundlich model (7B) for the adsorption of tannins on CCNC. 
Table 1. Concentrations of the main phenolic compounds in the concentrated tannin extract

\begin{tabular}{lcc} 
Compounds & Rt & $\mathbf{~ m g} / \mathbf{m l}$ \\
\hline Phenolic acids & 1.7 & 0.06 \\
Gallic acid & 3.9 & 0.06 \\
Protocatechuic acid & 4.5 & 0.06 \\
Cinnamic acid derivative & 13.4 & 0.11 \\
$p$-OH-Cinnamic acid & 14.5 & 0.05
\end{tabular}

\section{Flavonoids}

$\begin{array}{lll}(+)-C a t e c h i n & 9.9 & 0.04\end{array}$

$\begin{array}{lll}\text { Ampelopsin } & 12.4 & 0.09\end{array}$

$\begin{array}{lll}\text { Taxifolin } & 16.2 & 0.16\end{array}$

Stilbenes

$\begin{array}{lll}\text { Piceatannol } & 17.0 & 0.74\end{array}$

$\begin{array}{lll}\text { Methyl-Piceatannol monoglucoside } & 17.8 & 0.77\end{array}$

$\begin{array}{lll}\text { Resveratrol } & 22.3 & 0.09\end{array}$

$\begin{array}{lll}\text { Methyl-Piceatannol } & 23.2 & 0.10\end{array}$

Other phenols

$\begin{array}{lll}\text { Neolignan derivative } 1 & 15.8 & 0.09\end{array}$

$\begin{array}{lll}\text { Neolignan derivative } 2 & 21.7 & 0.07\end{array}$

$\begin{array}{lll}\text { Neolignan derivative } 3 & 24.6 & 0.07\end{array}$

$\begin{array}{lll}\text { Unknown polymer } & 25.3 & 0.04\end{array}$

Unknown polymer $\quad 26.0 \quad 0.06$

Unknown polymer $\quad 27.7 \quad 0.13$

$\begin{array}{lll}\text { Unknown polymer } & 28.1 & 0.13\end{array}$ 


\begin{tabular}{lcc} 
Unknown polymer & 30.8 & 0.04 \\
Unknown polymer & 31.9 & 0.05 \\
Unknown polymer & 33.7 & 0.03 \\
Unknown polymer & 34.2 & 0.02 \\
\hline Condensed tannins & & 21.23 \\
\hline
\end{tabular}


Table 2. Charge dependency, zeta potential and conductivity of tannin extract and CCNC particles (pH range 3-10)

\begin{tabular}{|c|c|c|c|c|c|}
\hline & 3 & 5 & 7 & 8 & 10 \\
\hline Tannin extract (- mmol/g) & 0.05 & 0.11 & 0.38 & 0.52 & 1.19 \\
\hline $\mathrm{CCNC}(+\mathrm{mmol} / \mathrm{g})$ & 2.24 & 2.46 & 2.20 & 1.98 & 1.33 \\
\hline \multicolumn{6}{|l|}{$\zeta$-potential } \\
\hline Tannin extract $(\mathrm{mV})$ & -17.90 & -19.17 & -11.56 & -22.13 & -15.50 \\
\hline $\mathrm{CCNC}(\mathrm{mV})$ & 18.97 & 23.77 & 20.6 & 17.17 & 18.97 \\
\hline \multicolumn{6}{|l|}{ Conductivity } \\
\hline Tannin extract $(\mathrm{mS} / \mathrm{cm})$ & 0.16 & 0.09 & 0.13 & 0.14 & 0.11 \\
\hline $\mathrm{CCNC}(\mathrm{mS} / \mathrm{cm})$ & 0.30 & 0.14 & 0.18 & 0.20 & 0.15 \\
\hline
\end{tabular}


Table 3. Estimated values of constants of kinetics for the adsorption of tannin extract to CCNCs

\begin{tabular}{cccc|ccc}
\hline \multicolumn{3}{c|}{ Pseudo- first- order kinetics model } & \multicolumn{3}{c}{ Pseudo- second- order kinetics model } \\
\hline Qe(Exp.) & Qe(Calc.) & $K i$ & $R^{2}$ & Qe(Calc. $)$ & $K a$ & $R^{2}$ \\
98.95 & 14.37 & 0.0013 & 0.32 & 99.01 & 0.00068 & 0.99 \\
\hline
\end{tabular}


Table 4. The parameters of Langmuir and Freundlich isotherms for the adsorption of tannins to cationic cellulose nanocrystals

\begin{tabular}{cccc|ccc}
\hline \multicolumn{3}{l|}{ Langmuir isotherm } & & \multicolumn{3}{l}{ Freundlich isotherm } \\
\hline$R l$ & $Q m(m g / g)$ & $K l\left(d m^{3} / m g\right)$ & $R^{2}$ & $K f\left(d m^{3} / m g\right)$ & $n F$ & $R^{2}$ \\
0.99 & 1111.1 & 0.018 & 0.98 & 2.46 & 1.63 & 0.83 \\
\hline
\end{tabular}

